\title{
EXPLORING THE IMPACT OF SOCIAL CAPITAL ON ENTREPRENEURIAL ORIENTATION AND BUSINESS PERFORMANCE \\ (Study on Members of MSMEs Communities in Malang)
}

\author{
Prakasa, Yudha \\ Lecturer of Business Administration Department, Universitas Brawijaya \\ Email: y.prakasa87@ub.ac.id
}

\begin{abstract}
ABSTRAK
Studi ini menjelaskan hubungan antara modal sosial dan kinerja usaha dengan orientasi kewirausahaan sebagai variabel antara. Penelitian dilakukan di 4 (empat) komunitas Usaha Mikro, Kecil dan Menengah (UMKM) di kota Malang dengan populasi sebanyak 324 pelaku usaha. Penarikan sampel menggunakan teknik Proportional Cluster Random Sampling, melibatkan 90 responden yang tergabung dalam komunitas UMKM dan menggunakan kuesioner sebagai alat pengumpulan data. Hasil penelitian dapat diketahui bahwa modal sosial secara signifikan dapat memepengaruhi orientasi kewirausahaan maupun kinerja usaha. Orientasi Kewirausahaan juga memiliki hubungan yang signifikan terhadap Kinerja Usaha. Modal Sosial memiliki pengaruh lebih besar terhadap Kinerja Usaha melalui Orientasi Kewirausahaan sebagai variabel antara.
\end{abstract}

Kata Kunci: Modal Sosial, Orientasi Kewirausahaan, Kinerja Usaha, UMKM

\begin{abstract}
This research analyzes the relationship between social capital and business performance with entrepreneurship orientation as an intermediary variable. This research was conducted in 4 (four) communities of micro, small and medium enterprises (MSMEs) in Malang city with a population of 324 business actors. Proportional Cluster Random Sampling technique was applied, involving 90 respondents who are members of the MSMEs community. The data was gathered through questionnaires. The findings showed that social capital significantly affects entrepreneurial orientation as well as business performance. It is also found that Entrepreneurship Orientation has a significant influence on Business Performance. Lastly, it is found that the effect of Social Capital on Business Performance was mediated by Entrepreneurial Orientation.
\end{abstract}

Keywords: Social Capital, Entrepreneurial Orientation, Business Performance, MSMEs 


\section{A. INTRODUCTION}

Putnam (1993) defines social capital formed a base on network, norms, and trusts among organizational members so as to cooperate in achieving organizational goals. Actually, a social capital concept in business can be illustrated as the occurrence of a relationship between business actors and material suppliers because of the trust among them and the relationship of the parties involved to obtain mutual benefits. This relationship is bound by prevailing norms, ease of relationship and pleasant experience so that the benefits gained will foster a sustainable relationship.

Indonesia is a country whose society is very collectivist (Hofstede, 1983) where the kinship relations of its members are very strong. Such societal characteristics have strong social capital and influence on institutional performance (Coleman, 1988 and Putnam, 1993). Nevertheless, Indonesia has a serious problem of poverty where $11.13 \%$ of the population is below the poverty line (BPS, 2016). The empowerment and entrepreneurial approach are believed to resolve social problems (Davidson and Burke, 2004). The concept of entrepreneurship can be developed through a social capital approach. Trust between business actors, reciprocal relationships based on trust is the basic capital in business development (Nahapiet \& Ghoshal 1998; Burt 2009), including solidarity networks formed in groups (Woolcock, 1999; Narayan, 1999; Mattessich, 2009). Therefore, social capital can believe to increase the effectiveness of community empowerment, increase incomes, and poverty alleviation.

The construct of social capital is mostly associated with micro, small and medium enterprises (MSMEs). Studies have shown that social capital can significantly improve the performance of MSMEs (Chen, et al, 2007; Boso, et al., 2013; Felicio, et al., 2014; Rapih, 2015). Previous studies based on the social capital framework also shown that trust-based social relationships contribute to indicators of business development (Nadvi 1999; Bowles \& Gintis 2002; Molina-Morales \& MartinezFernández 2010; Nam et al. 2010). Trust and reciprocal relationships in a group relationship will provide new ideas and information resources. Togetherness, honesty, egalitarianism, and trust developed in social capital will strengthen networks between entrepreneurs (Nugroho and Setyawan, 2015).

The concept of social capital from Gelderman et al. (2016) used in this study, which divides social capital into 3 dimensions, namely: (a) structural, (b) cognitive, and (c) relational. The inspired concept of Nahapiet (1998) thought is more operational, so it is widely used by social capital researchers.

The study uses innovation, proactiveness, and risk-taking as an indicator of the entrepreneurial orientation [taken from Covin and Slevin (1989) and Ejdys (2016)]. While the indicator of business performance refers to Dimon (2013) that economic performance, environmental performance, and social performance can be used to measure MSMEs business performance.

\section{B. THEORETICAL BACKGROUND}

\section{Social Capital and Business Performance}

Putnam (1995) state that the construct of social capital is a theory that can explain the relationship between individuals and groups. According to Coleman (1988), types of social capital namely: (a) Structure of obligations, expectations, and beliefs; (b) information channels; and (c) the effective norms and sanctions of Coleman (1988). Furthermore, Nahapiet and Ghoshal (1998) divide social capital into three dimensions: (a) Structural dimension, this dimension is associated with communication patterns and impersonal relationships between parties in social life (Burt, 2000; Gelderman, et al., 2016 ); (b) The cognitive dimension, this dimension is related to the similarity of cultural views, business philosophy, goals, and visions shared by various parties in social capital. Culture can be defined as the norm or value embodied in the behavior of various parties in social capital (Inkpen and Tsang, 2005; Gelderman et al., 2016) thus placing common interests above individual interests (Coleman, 1990); (c) Relational dimension, this dimension refers to trust, friendship, respect, and interaction built sustainably by all parties in social capital (Kale et al., 2000; Gelderman, et al., 2016). This continuous interaction can reduce dependence on formal contracts (Zaheer and Venkatraman, 1995). The highly collectivist character of Indonesian society is also shaped by the strength of the relational capital. 
Business performance is the effect of the process that converting various raw materials into valuable goods and services for targeted customers. Business performance, both large and small companies, can be measured from financial, economic, social, environmental, and business sustainability. Previous research has indicated that social capital plays a vital role in determining business performance as the findings of Chen et al (2007); Felicio, et al (2014); and Rapih (2015) which shows that the better the social capital, especially the MSME sector, the better the business performance. Furthermore, Dai, et al (2015) also found that social capital affects financial performance and organizational innovation. Therefore, the following hypothesis is proposed:

Hypothesis 1: Social Capital significantly affect Business Performance

\section{Social Capital and Entrepreneurial Orientation}

The entrepreneurship orientation is the core resource for enhancing the company's competitiveness sustainably (Conner, 1991). The characteristics of entrepreneurship, such as aggressive, innovative, independent and risktaking, can determine the company's competitive advantage. Many experts identify entrepreneurial orientation in various dimensions. Boso, et al (2013) describes 5 (five) dimensions of entrepreneurial orientation, namely: autonomy, innovative, proactive, competitive aggressiveness, and risk taking. Furthermore, Covin and Slevin (1989) and Ejdys (2016) state that the entrepreneurship orientation consists of 3 (three) dimensions: innovation, proactive, and risk taking. Recent studies by Rhee, et al (2010) and Liu et al (2014) only use proactive and risk-taking as factors that shape the entrepreneurial orientation.

As known, personal value is an individual preference that has a very strong influence in shaping one's behavior. Robbin (2013) divides the values into two categories, instrumental and terminal. Instrumental value is a way for individuals to achieve goals, such as honesty, responsibility, creativity, ability, independence, and ambition. Furthermore, the terminal value is the desired ending state of the application of the instrumental value believed, such as self-esteem, security, innovation, freedom, accomplishment, and happiness value. Nature, et al. (2015) found that personal values significantly affect entrepreneurial orientation. While social capital has an influence in shaping the value and behavior of a person so that the linkage between personal value, social capital, and entrepreneurial orientation becomes interested in. Previous studies (Chen, at al., 2007; Alarcon, et al., 2017) suggests that entrepreneurial orientation is determined by higher level of social capital so that the social capital as described is strongly influenced by the community value system.

Hypothesis 2: Social Capital significantly affect Entrepreneurial Orientation.

\section{Entrepreneurial Orientation and Business Performance}

Many organizational studies adopt contingency theory so there is no universality concept, therefore, the correlation among social capital and business performance is conditional. Özer and Tinaztepe (2014) use eleven indicators in appraising the performance of business organizations, namely: Qualified labor, Commitment, Job satisfaction, New product / service development capability, Product / service quality, Customer satisfaction, Sales growth, market growth, Return on sales, Return on assets, and Overall profitability. Previously, Dimon (2013) explained that there are 3 (three) indicators in assessing the performance of MSMEs, namely economic performance, environmental performance, and social performance. Furthermore, Dimon (2013) explains that social performance consists of labor practices and decent work, human rights, society, and product responsibility.

Accordingly, there is a positive correlation among social capital and business performance, but the effect will be stronger if the business actor has specific characteristics that support performance. The individual characteristic used in this research is entrepreneurial orientation. The past research has shown that entrepreneurial orientation significantly affect on organizational effectiveness (Fernandes-Mesa and Alegre, 2015; Martin and Javalgi, 2016; Nunez-Pomar et al., 2016; Vega-Vazquez et al., 2016). Previously, Chen, et al (2007); Boso, et al (2013); and also Mason, et al (2015) also 
revealed that business performance is significantly affected by entrepreneurial orientation. It shows that business performance can be improved if the business actors have an entrepreneurial orientation. All these considerations, the hypothesis has been formulated:

\section{Hypothesis 3: Entrepreneurial Orientation significantly affect Business Performance.}

Based on the literature reviewed above, the model of hypothesis used in this research is:

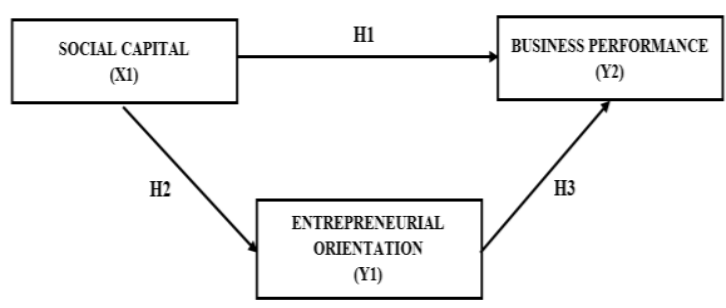

Figure 1. Model of Hypothesis

\section{RESEARCH METHOD}

This research uses research approach to the survey and quantitative method. In pursuance of the purpose of research, the approach used is descriptive explorative. This research is also aimed at explaining the influence among variables (explanatory) by doing a hypothesis test. The unit of analysis on this research is an individual or member of 4 (four) MSMEs community that located in Malang City, there are Preman Super Community, Amangtiwi Community, Rajut (knitting) Community, and AMR (Amazing Malang Raya) Community.

The population in the research were all members of 4 (four) MSME communities with the number of 324 business actors. Determination of samples using the Roscoe formulation, particularly at least 10 times the total of variables that utilized as a part of research. This examination utilized 30 times of the total of variables (three variables) so that the total sample of 90 respondents. The sampling technique used proportional cluster random sampling

Measurement scale using the Likert scale with the scale of point 1 (strongly disagree) to score 5 (strongly agree) to measure respondents' answers. The social capital variable consists of three indicators cited from Nahapiet et al. (1998) namely: the structural dimension, cognitive dimension, and relational dimension. The entrepreneurial orientation variable consists of three indicators cited from Covin and Slevin (1989) and Ejdys (2016), namely: pro-active, risk-taking, and innovation. While the business performance variable consists of three indicators cited from Dimon (2013) Specifically the performance of social, economic, and environmental. Social capital is an independent variable, entrepreneurial orientation as an intermediary variable, and business performance as a dependent variable.

Furthermore, this research uses primary data and collected by distributing questionnaires to MSMEs community members. Primary data is used as a reference to analyze the hypotheses that have been developed. To strengthen the results of the analysis, this study also uses secondary data, specifically literature, legislation, and other related documents. This study uses SPSS 20.0 as statistical tools to ascertain the profile of respondents and descriptive analysis, and use Smart PLS 3.0 to analyze the statistical results of whether Social capital can significantly improve entrepreneurial orientation and enterprise performance on members of the MSMEs community in Malang.

\section{RESULT AND DISCUSSION}

\section{Characteristics of Respondents}

Based on the tabulation of data from questionnaires that have been spread to all respondents, respondents characteristics are presented in full through Table 1.

Table 1. Profil of Respondents

\begin{tabular}{|c|c|c|c|}
\hline Criteria & Catagories & Frequency & $\begin{array}{c}\text { Percentage } \\
(\%)\end{array}$ \\
\hline \multirow[t]{2}{*}{ Gender } & Male & 10 & 11,1 \\
\hline & Female & 80 & 88,9 \\
\hline \multirow[t]{6}{*}{ Age } & $\leq 25$ & 1 & 1,1 \\
\hline & $>25-30$ & 4 & 4,4 \\
\hline & $>30-35$ & 13 & 14,4 \\
\hline & $>35-40$ & 19 & 21,1 \\
\hline & $>40-45$ & 11 & 12,2 \\
\hline & $>45$ & 42 & 46,7 \\
\hline \multirow{5}{*}{$\begin{array}{c}\text { Level } \\
\text { Education }\end{array}$} & PM & 1 & 1,1 \\
\hline & JHS & 11 & 12,2 \\
\hline & SHS & 42 & 46,7 \\
\hline & Diploma & 9 & 10 \\
\hline & Bachelor & 27 & 30 \\
\hline \multirow{5}{*}{$\begin{array}{c}\text { Business } \\
\text { Established }\end{array}$} & $>1 \mathrm{yr}-2 \mathrm{yr}$ & 25 & 27,8 \\
\hline & $>2 y r-4 y r$ & 29 & 32,2 \\
\hline & $>4 y r-6 y r$ & 13 & 14,4 \\
\hline & $>6 y r$ & 23 & 25,6 \\
\hline & Fashion & 11 & 12,2 \\
\hline
\end{tabular}




\begin{tabular}{|c|c|c|c|}
\hline Criteria & Catagories & Frequency & $\begin{array}{c}\text { Percentage } \\
(\%)\end{array}$ \\
\hline \multirow{3}{*}{$\begin{array}{l}\text { Types of } \\
\text { Business }\end{array}$} & Food/Culinary & 50 & 55,6 \\
\hline & Craft & 26 & 28,9 \\
\hline & Others & 3 & 3,3 \\
\hline \multirow{2}{*}{$\begin{array}{l}\text { Number of } \\
\text { Employees }\end{array}$} & $<5$ person & 71 & 78,9 \\
\hline & $5-20$ persons & 19 & 21,1 \\
\hline \multirow[t]{4}{*}{ Revenue/month } & < IDR 4.000K & 52 & 57,8 \\
\hline & $\begin{array}{c}\text { IDR } 4.000 \mathrm{~K}- \\
5.000 \mathrm{~K} \\
\end{array}$ & 24 & 26,7 \\
\hline & $\begin{array}{c}\text { IDR } 5.000 \mathrm{~K}- \\
10.000 \mathrm{~K}\end{array}$ & 8 & 8,9 \\
\hline & >IDR $10.000 \mathrm{~K}$ & 6 & 6,7 \\
\hline
\end{tabular}

Source: processed primary data, 2016

Table 1 shows that $88.9 \%$ of respondents are female with an average age of 35 to 40 years, besides that, $46,7 \%$ respondents have education level in senior high school and have engaged in business activities for 2 to 4 years. Most of the respondents (55.6\%) engaged in the food business sector, while the rest in the handicraft sector $(28.9 \%)$, fashion (12.2\%) and other sectors by $3.3 \%$. Furthermore, refers to the total of labors and business revenue, the majority of respondents are Micro and Small Business level.

\section{Descriptive Statistics}

The descriptive statistical analysis is expected to understand the respondent's impression of all questions in the survey. Completely, descriptive statistical analysis of social capital (X), entrepreneurship orientation (Y1) and business performance (Y2) are clarified below.

\subsection{Social Capital $(\mathrm{X})$}

The social capital variable $(\mathrm{X})$ consists of 18 questions divided into structural capital (8 questions), cognitive capital (5 questions), and relational capital (5 questions). Descriptive statistical results have shown that the mean value (variable) of Social Capital (X) is 4.29 indicating that social capital is very well applied by respondents in the MSMEs community. This is strengthened by the average structural value is 4.32 (very good), cognitive capital is 4.25 (very good) and relational capital is 4.30 (very good).

\subsection{Entrepreneurial Orientation (Y1)}

The Entrepreneurship Orientation Variable (Y1) consists of 11 questions divided into pro-active (4 questions), risk-taking (2 questions) and innovation (5 questions). Descriptive statistics results shown that the mean value (variable) of entrepreneurial orientation variables (Y1) is 4.09 which indicates that the respondents have a good entrepreneurial orientation. This is strengthened by the average pro-active value is 4.13 (good), risk-taking is 3.92 (good) and innovation is 4.22 (very good).

\subsection{Business Performance (Y2)}

Business Performance Variables (Y2) consists of 17 questions consisting of economic performance (5 questions), environmental performance (5 questions) and economic performance (7 questions). Descriptive statistics results show that the average value (mean) Business Performance variable (Y2) is 4.02 which indicates that the MSMEs business actors have a great business performance. This is strengthened by the average economic performance value is 3.94 (good), environmental performance is 4.05 (good) and social performance is 4.08 (very good).

\section{Statistics Analysis}

\subsection{Outer Model}

The early step of statistical analysis in this study is to test the validity and reliability of research instruments by using outer model so that can be known the relationship between indicators and latent variables (Ghozali, 2008). Validity is tested using convergent validity and discriminant validity method, while reliability is tested using composite reliability method (Abdillah and Jogiyanto, 2015). The rules for convergent validity is outer loading $>0.7$, communality $>0.5$ and Average Variance Extracted (AVE) $>0.5$ (Chin, 1995 in Abdillah and Jogiyanto, 2015).

Refers to the test of convergence validity (outer loading) results, it is known that item Y1.2.1 from Entrepreneurial Orientation (Y1) has an outer loading value less than 0.7. It means that item Y1.2.1 (MSMEs community encourages its members to dare to take highrisk project) cannot be used to measure the entrepreneurial orientation variable, so the Y1.2.1 item is removed from the research model. 


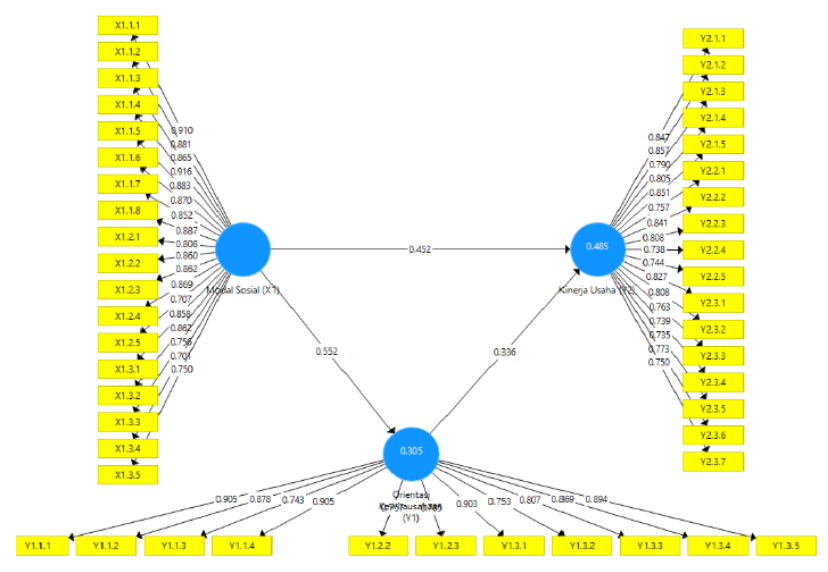

Figure 2. The result of Outer Loading Measurement

Figure 2 shows that each item that measures the variables of Social Capital, Entrepreneurship Orientation, and Business Performance has values above 0.7 so as to satisfy the convergent validity. Furthermore, the result of Average Variance Extracted (AVE) calculation shows that all research variables have value more than 0.5 , Composite Reliability (CR) $\geq 0.7$ and Cronbach's Alpha $\geq 0.6$. Table 2 shown that the convergent validity has satisfied.

Table 2. The result of AVE and CR measurement

\begin{tabular}{|l|c|c|c|c|}
\hline & $\begin{array}{c}\text { Cronbach's } \\
\text { Alpha }\end{array}$ & rho_A & AVE & CR \\
\hline $\begin{array}{l}\text { Business } \\
\text { Performance } \\
\text { (Y2) }\end{array}$ & $\mathbf{0 , 9 6 2}$ & $\mathbf{0 , 9 6 4}$ & $\mathbf{0 , 6 2 6}$ & $\mathbf{0 , 9 6 6}$ \\
\hline $\begin{array}{l}\text { Social Capital } \\
\text { (X1) }\end{array}$ & $\mathbf{0 , 9 7 5}$ & $\mathbf{0 , 9 7 7}$ & $\mathbf{0 , 7 0 8}$ & $\mathbf{0 , 9 7 7}$ \\
\hline $\begin{array}{l}\text { Entrepreneurial } \\
\text { Orientation } \\
\text { (Y1) }\end{array}$ & $\mathbf{0 , 9 5 7}$ & $\mathbf{0 , 9 6 1}$ & $\mathbf{0 , 7 0 3}$ & $\mathbf{0 , 9 6 3}$ \\
\hline
\end{tabular}

Source: processed primary data, 2016

Tabel 3. Discriminant validity of the construct

\begin{tabular}{|c|c|c|c|}
\hline & $\begin{array}{c}\text { Business } \\
\text { Performance } \\
\text { (Y2) }\end{array}$ & $\begin{array}{c}\text { Social } \\
\text { Capital } \\
\text { (X1) }\end{array}$ & $\begin{array}{c}\text { Entrepreneurial } \\
\text { Orientation } \\
\text { (Y1) }\end{array}$ \\
\hline $\begin{array}{c}\text { Business } \\
\text { Performance } \\
\text { (Y2) }\end{array}$ & $\mathbf{0 . 7 9 1}$ & 0.638 & 0.585 \\
\hline $\begin{array}{c}\text { Social Capital } \\
\text { (X1) }\end{array}$ & 0.638 & $\mathbf{0 . 8 4 1}$ & 0.552 \\
\hline $\begin{array}{c}\text { Entrepreneurial } \\
\text { Orientation } \\
\text { (Y1) }\end{array}$ & 0.585 & 0.552 & $\mathbf{0 . 8 3 9}$ \\
\hline
\end{tabular}

Source: processed primary data, 2016

The second test to determine the validity of an item is done by comparing the roots of the average variance extracted (AVE) with the correlation among the same latent variables. Table
3 shows that the square root of AVE is larger than the correlations with other constructs. Diagonals (in bold) describe the average variance extracted while the other entries state the squared correlations. Furthermore, the result of discriminant validity test using cross loading parameter shows that correlation of social capital construct, entrepreneurship orientation, and business performance with all indicators have the higher value (in bold) compared with correlation construct of other variables. Table 4, Table 5, and Table 6 show the results of cross loading.

Table 4. Cross Loading of Social Capital

\begin{tabular}{|c|c|c|c|}
\hline & BP (Y2) & SC $(\mathbf{X 1})$ & EO (Y1) \\
\hline $\mathrm{X} 1.1 .1$ & 0.594 & 0.910 & 0.503 \\
\hline $\mathrm{X} 1.1 .2$ & 0.513 & 0.881 & 0.437 \\
\hline $\mathrm{X} 1.1 .3$ & 0.540 & 0.865 & 0.456 \\
\hline $\mathrm{X} 1.1 .4$ & 0.594 & 0.916 & 0.520 \\
\hline $\mathrm{X} 1.1 .5$ & 0.580 & 0.883 & 0.473 \\
\hline $\mathrm{X} 1.1 .6$ & 0.504 & 0.870 & 0.439 \\
\hline $\mathrm{X} 1.1 .7$ & 0.492 & 0.852 & 0.456 \\
\hline $\mathrm{X} 1.1 .8$ & 0.580 & 0.887 & 0.499 \\
\hline $\mathrm{X} 1.2 .1$ & 0.506 & 0.808 & 0.460 \\
\hline $\mathrm{X} 1.2 .2$ & 0.544 & 0.860 & 0.520 \\
\hline $\mathrm{X} 1.2 .3$ & 0.540 & 0.862 & 0.425 \\
\hline $\mathrm{X} 1.2 .4$ & 0.564 & 0.869 & 0.478 \\
\hline $\mathrm{X} 1.2 .5$ & 0.502 & 0.707 & 0.431 \\
\hline $\mathrm{X} 1.3 .1$ & 0.578 & 0.858 & 0.512 \\
\hline $\mathrm{X} 1.3 .2$ & 0.575 & 0.862 & 0.537 \\
\hline $\mathrm{X} 1.3 .3$ & 0.501 & 0.756 & 0.446 \\
\hline $\mathrm{X} 1.3 .4$ & 0.447 & 0.701 & 0.377 \\
\hline $\mathrm{X} 1.3 .5$ & 0.450 & 0.750 & 0.327 \\
\hline
\end{tabular}

Source: processed primary data, 2016

Table 5. Cross Loading of Entrepreneurial Orientation

\begin{tabular}{|c|c|c|c|}
\hline & BP (Y2) & EO (Y1) & SC (X1) \\
\hline Y1.1.1 & 0.538 & 0.905 & 0.481 \\
\hline$Y 1.1 .2$ & 0.532 & 0.878 & 0.494 \\
\hline Y1.1.3 & 0.433 & 0.743 & 0.415 \\
\hline$Y 1.1 .4$ & 0.544 & 0.905 & 0.482 \\
\hline$Y 1.2 .2$ & 0.428 & 0.757 & 0.420 \\
\hline$Y 1.2 .3$ & 0.431 & 0.785 & 0.405 \\
\hline$Y 1.3 .1$ & 0.517 & 0.903 & 0.475 \\
\hline Y1.3.2 & 0.422 & 0.753 & 0.463 \\
\hline$Y 1.3 .3$ & 0.447 & 0.807 & 0.418 \\
\hline$Y 1.3 .4$ & 0.521 & 0.869 & 0.485 \\
\hline$Y 1.3 .5$ & 0.554 & 0.894 & 0.534 \\
\hline
\end{tabular}

Source: processed primary data, 2016 
Table 4. Cross Loading of Business Performance

\begin{tabular}{|c|c|c|c|}
\hline & SC $(\mathbf{X 1})$ & BP $(\mathbf{Y} 2)$ & EO $(\mathbf{Y} 1)$ \\
\hline Y2.1.1 & 0,564 & 0,847 & 0,486 \\
\hline Y2.1.2 & 0,541 & 0,857 & 0,515 \\
\hline Y2.1.3 & 0,603 & 0,790 & 0,553 \\
\hline Y2.1.4 & 0,483 & 0,805 & 0,472 \\
\hline Y2.1.5 & 0,532 & 0,851 & 0,511 \\
\hline Y2.2.1 & 0,558 & 0,757 & 0,450 \\
\hline Y2.2.2 & 0,555 & 0,841 & 0,489 \\
\hline Y2.2.3 & 0,475 & 0,808 & 0,483 \\
\hline Y2.2.4 & 0,450 & 0,738 & 0,356 \\
\hline Y2.2.5 & 0,535 & 0,744 & 0,402 \\
\hline Y2.3.1 & 0,530 & 0,827 & 0,478 \\
\hline Y2.3.2 & 0,416 & 0,808 & 0,488 \\
\hline Y2.3.3 & 0,404 & 0,763 & 0,409 \\
\hline Y2.3.4 & 0,449 & 0,739 & 0,511 \\
\hline Y2.3.5 & 0,489 & 0,735 & 0,367 \\
\hline Y2.3.6 & 0,447 & 0,773 & 0,478 \\
\hline Y2.3.7 & 0,483 & 0,750 & 0,368 \\
\hline
\end{tabular}

Source: processed primary data, 2016

\subsection{Inner Model}

Inner model testing is needed to verify the correlation among constructs, significance values, and R-square of the research model (Ghozali, 2008). Table 5 shows that Social Capital Variable gives $30,5 \%$ effect to Entrepreneurship Orientation variables, while the remaining $69.5 \%$ is affected by other factors or variables that are not found in equation model in this research. While the variable of Social Capital and Entrepreneurial Orientation give effect to Business Performance variable equal to $47.3 \%$, the rest of effect to Business Performance variable affected by other factor or variable not found in equation model in this research.

Table 5. R-Square Measurement

\begin{tabular}{|c|c|c|}
\hline & R Square & $\begin{array}{c}\text { R Square } \\
\text { Adjusted }\end{array}$ \\
\hline $\begin{array}{c}\text { Business } \\
\text { Performance (Y2) }\end{array}$ & 0,485 & 0,473 \\
\hline $\begin{array}{c}\text { Entrepreneurial } \\
\text { Orientations (Y1) }\end{array}$ & 0,305 & 0,297 \\
\hline
\end{tabular}

Source: processed primary data, 2016

Q-Square calculation results also show that the value of Q-Square of $0.629519>0$ so that in accordance with predictive relevance criteria. Specifically, this research model is feasible to use in prediction.

Table 6 verifies that all hypotheses are accepted. It is evident that all hypotheses in this study are accepted. First, social capital significantly affects Business Performance with coefficient value is 0.452 significant at the alpha level of 5\%. This is strengthened by the result of $T$ Statistics value $(4,150)$ is also greater than t table (1.96). That is, the better implementation of social capital in MSMEs community will have an impact on the increased business performance of members of the MSMEs community.

Table 6. Path Coefficient

\begin{tabular}{|l|c|c|c|c|c|}
\hline & $\begin{array}{c}\text { Original } \\
\text { Sample } \\
(\mathbf{O})\end{array}$ & $\begin{array}{c}\text { Sample } \\
\text { Mean } \\
(\mathbf{M})\end{array}$ & $\begin{array}{c}\text { Standard } \\
\text { Deviation } \\
\text { (STDEV) }\end{array}$ & $\begin{array}{c}\text { T Statistics } \\
(\mid \text { O/STDEV|) }\end{array}$ & $\begin{array}{c}\text { P } \\
\text { Values }\end{array}$ \\
\hline $\begin{array}{l}\text { SC (X1) -> } \\
\text { BP (Y2) }\end{array}$ & 0.452 & 0.472 & 0.109 & 4.150 & 0.000 \\
\hline $\begin{array}{l}\text { SC (X1) -> } \\
\text { EO (Y1) }\end{array}$ & 0.552 & 0.571 & 0.070 & 7.874 & 0.000 \\
\hline $\begin{array}{l}\text { EO (Y1) -> } \\
\text { BP (Y2) }\end{array}$ & 0.336 & 0.324 & 0.099 & 3.382 & 0.001 \\
\hline
\end{tabular}

Source: processed primary data, 2016

Secondly, social capital significantly affects entrepreneurial orientation with coefficient value is 0,552 significant at the alpha level 5\%. The result of $T$ Statistics value $[7,874$ $\geq 1.96(t$ table $)]$ fortifies the effect of social capital on entrepreneurial orientation. Indeed, the better execution of social capital in MSMEs communities, the higher entrepreneurial orientation owned by MSMEs business actors. Third, Entrepreneurial Orientation significantly affects Business Performance with coefficient value is 0.336 significant at the alpha level of $5 \%$. T Statistics value $(3,382)$ which is greater than $t$ table $(1,96)$ also shows the effect of these two variables. This shows that the better the entrepreneurship orientation owned by MSMEs business actors will have an impact on the increasing of Business Performance.

Based on the original sample estimate value, social capital has the greatest impact on entrepreneurial orientation. Social capital also has a greater impact on business performance than on entrepreneurial orientation.

Table 7. Indirect Effects

\begin{tabular}{|c|c|c|c|}
\hline $\begin{array}{c}\text { Business Performance } \\
\text { (Y2) }\end{array}$ & BP (Y2) & SC (X1) & EO (Y1) \\
\hline Social Capital (X1) & 0.185 & & \\
\hline $\begin{array}{c}\text { Entrepreneurial } \\
\text { Orientations (Y1) }\end{array}$ & & & \\
\hline
\end{tabular}

Source: processed primary data, 2016

Moreover, social capital has indirect correlations of 0.185 on business performance through Entrepreneurial Orientation (Table 7). 
In addition, social capital has an effect of 0.673 to Business Performance based on the sum of direct (0.452) and indirect effects (0.185). Finally, social capital effect on business performance will be higher if the MSMEs business actors have a good entrepreneurial orientation

\section{Discussion}

As we know, all hypotheses of this research are accepted. The first hypothesis, there is significant influence on Social Capital to Business Performance is proven acceptable (H1 accepted). These results indicate that the use of social capital in the MSMEs community will have a positive effect on the enterprise performance of community members. These findings support previous research conducted by Chen, et al (2007); Felicio, et al (2014); Rapih (2015), and Dai, et al (2015) which stated that the performance of MSMEs is influenced by social capital of MSMEs actors. Furthermore, Social Capital has a significantly higher impact on Business Performance if community members have a good entrepreneurial orientation.

The second hypothesis of this study is also acceptable (H2 acceptable): Social capital has influenced by Entrepreneurial Orientation. That is to say, the implementation of social capital in the MSME community will have a positive effect on the entrepreneurial orientation of community members. These findings reinforce research results from Chen, at al (2007) and Alarcon, et al (2017).

This study also prove that there is a significantly influence on Entrepreneurial Orientation to Business Performance (H3 accepted). These results state that the entrepreneurial orientation has a positively affect on business performance of community members. This supports the research of Chen, et al (2007); Boso, et al (2013); FernandesMesa and Alegre (2015); Martin and Javalgi (2016); Mason, et al (2015); Nunez-Pomar, et al (2016); and Vega-Vazquez, et al, (2016) which reveal that Entrepreneurial Orientation is decidedly influenced by Business Performance.

\section{E. CONCLUSIONS AND SUGGESTIONS}

\section{Conclusions}

The results of this study indicate that the enterprise performance can be influenced by social capital and entrepreneurial orientation owned by MSMEs business actors.

1. Structural Capital, Innovation, and Social Performance have the largest contribution of each research variable based on descriptive analysis with consecutive values of 4.32 (very good), 4.22 (very good), and 4,02 (very good).

2. The result of hypothesis test proved that Social Capital has a significant influence on Entrepreneurial Orientation; Entrepreneurial Orientation a significant effect on Business Performance, and Social Capital a significant effect on Business Performance. Social Capital Variable and Entrepreneurship Orientation give influence to Business Performance variable equal to $47.3 \%$, while $52,7 \%$ the rest is influenced by other factor or variable not found in equation model in this research

\section{Suggestions}

Based on the results of the research, to improve the competitiveness of MSMEs, the MSMEs community needs to strengthen the cognitive capital of community members, more daring to take business risks and improve economic performance.

Furthermore, cognitive capital and relational capital have to increase by MSMEs business actor as a way to improve entrepreneurial orientation and business performance.

\section{F. REFERENCES}

Abdillah, Willy dan Jogiyanto. (2015). Partial Least Square (PLS), Alternatif Structural Equation Modeling (SEM) dalam Penelitian Bisnis [Partial Least Square (PLS) as an alternative of Structural Equation Modeling (SEM) on Business Research]. 1st Edition. Yogyakarta: ANDI

Adler, P. S., Kwon Seok-Woo, (2002). Social Capital: Prospect A New Concept. Academy of Management Review 2002, Vol.27, No. 1, 17-40. 
Alam, Syed Shah, Rohani Mohd, Badrul Hisham Kamaruddin, Noor Gani Mohd Nor, (2013). Personal values and entrepreneurial orientations in Malay entrepreneurs in Malaysia Mediating role of self-efficacy. International Journal of Commerce and Management Vol. 25 No. 4, pp. 385-401

Alarcon, Job Redrigo, Pedro M Gracia, Maria J. Ruiz Ortega, (2017). From social capital to entrepreneurial orientation: The mediating role of dynamic capabilities. European Management Journal

Arikunto, Suharsimi. (2006). Prosedur penelitian suatu pendekatan praktis [The research procedure is a practical approach]. VI revision edition. PT. Rineka Cipta. Jakarta.

BPS. (2006). Analisis Profil Perusahaan / Usaha Indonesia: Hasil Pendafttaran Perusahaan/Usaha Sensus Ekonomi 2006 [Analysis of Indonesia Company/Business Profile: Results of Company/Business Registration / Economic Census 2006]. BPS Katalog, 9102004. Jakarta

BPS. (2016). Keadaan Ketenagakerjaan Februari 2016 [Labor Conditions on February 2016]. Official Statistic News of Statistic Indonesia. No. 46/05/Th. XIX.

BPS. (2016). Profil Kemiskinan di Indonesia September 2015 [Profile of Poverty in Indonesia on September 2015]. Official Statistic News of Statistic Indonesia. No. 05/01/Th. XIX.

Burt, RS. (2009). Structural holes: The social structure of competition, Harvard University Press.

Burt, R.S., (2000). The network structure of social capital In: Staw, B.M., Sutton, R.I. (Eds.), Research in Organizational Behavior. Elsevier Science JAI, Amsterdam, London and NewYork, pp. 345-423.

Boso, Nathaniel, Vicky M. Story, John W. Cadogan, (2013). Entrepreneurial orientation, market orientation, network ties, and performance: Study of entrepreneurial firms in a developing economy. Journal of Business Venturing 28 (2013) 708-727

Bowles, S \& Gintis, H, (2002). Social capital and community governance, Economic Journal, vol. 12, no. November pp. 419436.

Casson, M., Yeung, B., Basu, A., and Wadeson, N. (ed). (2006). The Oxford Handbook of Entrepreneurship. New York: Oxford University Press Inc.

Chen, Cheng Nan, Lun-Chung T, Wei-Ming A., (2007). The Relationship among Social Capital, Entrepreneurial Orientation, Organizational Resources and Entrepreneurial Performance for New Ventures. Contemporary Management Research, Vol 3, No. 3 pp. 213-232.

Coleman, James S. (1988). Social Capital in the Creation of Human Capital. The American Journal of Sociology, Vol. 94.

Coleman, James S., (1990). Foundations of Social Theory. The Bellknap Press Of Harvard University, Cambridge, MA

Conner, K. R., (1991). A historical comparison of resource-based theory and five schools of thought within industrial organization economics: do we have a new theory of firms? Journal of Management, 17(1), 121-154.

Covin, J. G., and Slevin, D. P., (1989). Strategic management of small firms in a hostile and benign environment. Strategic Management Journal, 10, 75-87.

Croitoru, Alin., (2012). Schumpeter, J.A., 1934 (2008), The Theory of Economic Development: An Inquiry into Profits, Capital, Credit, Interest and the Business Cycle, translated from the German by Redvers Opie, New Brunswick (U.S.A) and London (U.K.) Transaction Publishers: A review of a book that is 100 years old. Journal of Comparative Research in Anthropology And Sociology, Vol 3, No. 2.

Dai, Weiqi (David), Zhenxing (Eddie) Mao, Xinyuan (Roy) Zhao, Anna S. Mattila. (2015). How does social capital influence the hospitality firm's financial performance? The moderating role of entrepreneurial activities. International 
Journal of Hospitality Management, Vol 51, pp 42-55.

Davidson, M., and Burke, R., (2004). Women in Management Worldwide: Facts, Figures, and Analysis. Ashgate: Cornwall.

Dimon, Ron. 2013. Enterprise Performance Management. Wiley CIO Series.

Ejdys, Joanna., (2016). Entrepreneurial Orientation vs. Innovativeness of Small and Medium Size Enterprises. Journal of Engineering, Project, and Production Management. 2016, 6(1), 13-24

Felício, J. A., Cuoto E., Caiado, J., (2014). Human capital, social capital and organizational performance. Management Decision, Vol. 52 Issue. 2, pp. 350 - 364.

Fernandez-Mesa, Anabel \& Joaquin Alegre., (2015). Entrepreneurial orientation and export intensity: Examining the interplay of organizational learning and innovation. International Business Review, Vol. 24 Issue 1, pp. 148-156.

GEDI. (2016). Global Entrepreneurship Index 2016. The Global Entrepreneurship and Development Institute.

Gelderman, Cees J., Janjaap Semeijn, Patrique P. Mertschuweit, (2016). The impact of social capital and technological uncertainty on strategic performance: The supplier perspective. Journal of Purchasing \& Supply Management.

Ghozali, Imam. (2008). Structural Equation Modeling, Metode Alternatif Dengan Partial Least Square [Structural Equation Modeling, alternative method of Partial Least Square]. Semarang. Undip Press.

Hair, J., Anderson, R., Tatham, R. \& Black, W. (1995). Multivariate data analysis. 7th Ed. Pearson Prentice Hall. New Jersey.

Hartono, Rudy, Suegianto, Enny Noegraheni H. (2013). Analisis Pengaruh Modal Sosial dan Orientasi Kewirausahaan terhadap Kinerja Kewirausahaan pada PT. Mentari Esa Cipta [Analysis of the Effect of Social Capital and Entrepreneurial Orientation on Entrepreneurship Performance at PT. Mentari Esa Cipta]. Undergraduate Thesis, BINUS.
Inkpen, A.C., Tsang, E.W.K., (2005). Social capital, networks, and knowledge transfer. Academic of Management Review. 30 (1), 146-165.

Kale, P., Singh, H., Perlmutter, H., (2000). Learning and protection of proprietary assets in strategic alliances: building relational capital. Strategic Management Journal. 21 (2), 217-228.

Kementerian Koperasi dan UKM [Ministry of Cooperation and Small Medium Enterprises]. (2012). Kemenkop Matangkan Skim Kredit Khusus bagi Wirausaha Pemula. http://www.depkop.go.id/content/read/k emenkop-matangkan-skim-kreditkhusus-wirausaha-pemula/.

Khoirrini, L., Kartika L. (2014). Pengaruh Modal Insani dan Modal Sosial terhadap Kinerja: Studi Kasus Usaha Kecil dan Menengah (UKM) Makanan dan Minuman Kota Bogor [Influence of Human Capital and Social Capital on Performance: Case Study of Small and Medium Enterprises (SMEs) Food and Beverage in Bogor]. Jurnal Manajemen dan Organisasi, Vol V, No 3, December 2014.

Levine, D.M., Stephan D.F., Krehbiel T.C., Berenson, M.L, (2011). Statistic for managers: using Microsoft Excel. New Jersey: Prentice Hall.

Liu, H., Ding, X.-h., Guo, H., and Luo, J.-h. (2014). How does slack affect product innovation in high-tech Chinese firms: The contingent value of entrepreneurial orientation. Asia Pacific Journal of Management, 31(1), 47-68.

Manson, M.C., Jasonanco F, Stefano M, Federic B, Roberto C., (2015). Understanding the Impact of Entrepreneurial Orientation on Smes' Performance. the Role of the Financing Structure. Procedia Economics and Finance. Vol. 23, pp. 1649-1661.

Martin, S.L., and Javalgi, R.G., (2016). Entrepreneurial Orientation, Marketing Capabilities, and Performance: The Moderating role of Competitive Intensity on Latin American International New 
Ventures. Journal of Business Research. Vol. 69 Issue 6, pp. 2040-2051.

Mattessich, P. W., (2009). Social capital and community building. In R. Phillips \& .H. Pittman (Eds.), An introduction to community development. pp. 49-57. London: Routledge.

Molina-Morales, FX \& Martinez-Fernández, MT., (2010). Social networks: effects of social capital on firm innovation, Journal of Small Business Management vol. .48, no. 22, pp. 258-279.

Munizu, Musran. 2010. Pengaruh FaktorFaktor Eksternal dan Internal Terhadap Kinerja Usaha Mikro dan Kecil (UMK) di Sulawesi Selatan [The Influence of External and Internal Factors on the Performance of Micro and Small Enterprises (MSEs) in South Sulawesi]. Jurnal Manajemen Dan Kewirausahaan, Vol.12, No. 1, page: 33-41

Nahapiet, J \& Ghoshal, S. (1998), Social capital, intellectual capital, and the organizational advantage, Academy of Management Review, vol. 23, no. 2, pp. 242-266.

Nadvi, Khalid., (1999). Shifting ties: Social networks in the surgical instrument cluster of Sialkot, Pakistan, Development and Change, vol. 30, no. 141-175.

Nam, VH, Sonobe, T \& Otsuka, K., (2010). An inquiry into the development process of village industries: The case of a knitwear cluster in Northern Vietnam, Journal of Development Studies vol. 46, no. 2, pp. 312-330.

Nan Chen, Cheng., Lun-Chung Tzeng, WeiMing Ou, Kai-Ti Chang., (2007). The Relationship among Social Capital, Entrepreneurial Orientation, Organizational Resources and Entrepreneurial Performance for New Ventures. Contemporary Management Research.

Narayan, DP., (1999). Bonds and Bridges, Social capital and poverty. Policy Research Working Paper Volume 2167, World Bank

Nugroho, Sidiq Pramono, Anton Agus S. (2015). Pemoderasian Modal Sosial Pada Pengaruh Orientasi Entrepreneur terhadap Peningkatan Kinerja Organisasi: Studi Empiris pada UKM di Kota Surakarta [Moderation of Social Capital on the Effect of Entrepreneur Orientation on Organizational Performance Improvement: Empirical Study on SMEs in Surakarta City]. BENEFIT Jurnal Manajemen dan Bisnis. Vol 19 No. 1 pp 80-94.

Núñez-Pomar, J., Prado-Gascó, V., Sanz, V. A., Hervás, J. C., \& Moreno, F. C., (2016). Does size matter? Entrepreneurial orientation and performance in Spanish sports firms. Journal of Business Research. Vol. 69 Issue 11, pp. 53365341.

Özer, Funda, Tinaztepe, Cihan., (2014). Effect of Strategic Leadership Styles on Firm Performance: A study in a Turkish SME. Procedia - Social and Behavioral Sciences 150 (2014) 778 - 784.

Prasetyo, Tommy., Harjanti Dhyah., (2013). Modal Sosial Pengusaha Mikro dan Kecil Sektor Informal dan Hubungannya Dengan Kinerja Bisnis di Wilayah Jawa Timur [Social Capital of Micro and Small Entrepreneur Informal Sector and Its Relationship to Business Performance in East Java Region]. AGORA Vol. 1, No. 3.

Putnam, R.D., (1993) Making Democracy Work: Civic Traditions in Modern Italy. Princeton, NJ: Princeton University Press.

Putnam, R.D., (1995). Tuning in, tuning out: The strange disappearance of social capital in America. Political Sci. Politics 28 (4), 664-683.

Rapih, Subroto. (2015). Analisis Pengaruh Kompetensi Sumberdaya Manusia, Modal Sosial dan Modal Finansial, Terhadap Kinerja UMKM Bidang Garmen di Kabupaten Klaten [Analysis of the Influence of Human Resource Competence, Social Capital, and Financial Capital, Against UMKM Performance of Garment Field in Klaten Regency]. Thesis. Digilib.uns.ac.id

Rhee, J., Park, T., and Lee, D. H., (2010). Drivers of innovativeness and performance for innovative SMEs in 
South Korea: Mediation of learning orientation. Technovation, 30(1), 65-75.

Riduwan \& Kuncoro. (2011). Cara Menggunakan dan Memakai Analisis Jalur [How to use Path Analysis]. Bandung: Alfabeta

Robbins, S. P., and Judge, T. (2013). Organizational Behavior. 15th edition. Boston: Pearson.

Sen S., Cowley J. (2013). The Relevance of Stakeholder Theory and Social Capital Theory in the Context of CSR in SMEs: An Australian Perspective. J Bus Ethics (2013) 118:413-427.

Spence, Laura J., Schmidpeter R. (2003). MEs, social capital, and the common good. Journal of Business Ethics; Jun 2003; 45, 1/2; Arts \& Humanities Database pg. 93.

Spence, Laura J., Schmidpeter R., Habisch, Andre., (2016). Assessing Social Capital: Small and Medium Sized Enterprises in Germany and the U.K. Report Information from ProQuest.

Tambunan, Tulus. (1994), Rural small-scale industries in a developing region: sign of poverty or progress? A case study in Ciomas Subdistrict, West-Java Province, Indonesia, Entrepreneurship and Regional Development, vol. 6, pp. 1-13.

Tambunan, Tulus. (2009). SMEs in Asian developing countries, Palgrave Macmilllan, New York.

Tambunan, Tulus. (2012). Usaha Mikro Kecil dan Menengah di Indonesia: Isu - isu penting [Small and Medium Micro Enterprise in Indonesia: Important Issues]. LP3ES. Jakarta.

Tippe, G., (2005). The place of home-based enterprises in the informal sector: Evidence from Cochabamba, New Delhi, Surabaya, and Pretoria, Urban Studies, vol. 42, no. 4, pp. 611-632.

Vega-Vázquez, M., Cossío-Silva, F.-J., \& Revilla-Camacho, M.-Á., (2016). Entrepreneurial orientation-hotel performance: Has market orientation anything to say? Journal of Business Research, 1-6.

Woolcock, M., (1998). Social capital and economic development: Toward a theoretical synthesis and policy framework. Theory and Society 27 (2): 151-208

Wong, Sam., (2007). Exploring 'Unseen' Social Capital in Community Participation: Everyday Lives of Poor Mainland Chinese Migrants in Hong Kong. Amsterdam University Press.

Zaheer, A., Venkatraman, N., (1995). Relational governance as an interorganizational strategy: an empirical test of the role of trust in economic exchange. Strategic Management Journal. 16 (5), 373-392. 